\title{
Indonesian EYL Curriculum Issues: Between Education Policy and Classroom Practices
}

\author{
Anne Ratna Suminar ${ }^{1}$, Pipih Setiawati ${ }^{2}$, Lucky Rahayu Nurjamin ${ }^{3}$, Yustika Nur Fajriah ${ }^{4}$ \\ \{anners@institutpendidikan.ac.id ${ }^{1}$, pipih@institutpendidikan.ac.id ${ }^{2}$, \\ luckyrahayu@institutpendidikan.ac.id ${ }^{3}$, yustikanurfajriah@institutpendidikan.ac.id ${ }^{4}$ \} \\ Institut Pendidikan Indonesia, Jalan Terusan Pahlawan No.32 Sukagalih - Tarogong Kidul, Garut
}

\begin{abstract}
This study is aimed at analyzing curriculum intent and implementation in English for young learners (EYL) classroom, conducted in a private junior high school in Indonesia. The participant in this study is an English teacher who teaches all grades. Nonparticipant classroom observations, document analysis and interview were carried out as the instruments. The collected data were then analyzed inductively. As a result, there is mismatch between the planned curriculum, using student-centered curriculum, and the delivered curriculum, teacher-centered curriculum. Therefore, this finding suggests that the government undertake the appraisal and the evaluation to English teaching practice secondary school level, followed up by supporting the teachers ' forum with activities; such as, in-house training, lesson study, peer teaching.
\end{abstract}

Keywords: English for Young Learners, curriculum intent, 2013 curriculum, SchoolBased Curriculum, Education Policy, Classroom Practices

\section{Introduction}

Teaching English for Young Learners (EYL) in Indonesia is provided in two types of education settings, i.e., formal education and non-formal education. Concerning formal education, the Indonesian education bureaucracy establishes 2013 curriculum as the latest secondary level curriculum. The language policy of 2013 curriculum arranges the allocated time of English teaching in Secondary School Level into 4 hours a week [1]. This allocated time is still better than the English teaching in Primary School Level which is removed from the curriculum.

Preceeding the 2013 curriculum, Indonesian curriculum has experienced alteration at least five times since 1945, after Indonesian's independency [2], [3]. Those five previous curricula have 2 differences with the 2013 curriculum. First, the approaches applied in English language teaching varied from Grammar Translation Method, Audiolingual Method, Communicative Approach, and Genre-Based Approach respectively; meanwhile, 2013 curriculum gives emphasis to moral education, practical and functional skills, and learner-centeredness [2], [4], [5]. Second, unlike the five curricula, the 2013 curriculum uses summative assesment and is also projected to use formative evaluation [6], [7]. This indicates that the students take the exams in the end or after the implementation and along with the teachers, the students also obtain information in the form of feedback as formative evaluation proposes [8].

Despite the differences, the 2013 curriculum also has similarity with School-Based Curriculum in term of two forms of objectives such as core competence and basic competence 
[4]. However, in the launching of 2013 curriculum, pros and cons regarding the preparation of teachers to implementation occured. This issue was supported by the findings of several empirical studies which revealed that the implementation of 2013 curriculum did not only signify not really maximal result but also did not completely run well in Secondary School Level [9], [10].

Based on the issues above the present study attempted to explore EYL curriculum issues concerning the education policy and classroom practices. The study addresses two research questions as follows :

1. How is the 2013 curriculum intent and implementation in the Secondary School level compatible with the list of curriculum indicators?

2. What is the implication of education policy in 2013 curriculum towards the classroom practices?

\section{Method}

This study was conducted in one private secondary school in Indonesia. The participant in this study was one English teacher who taught all grades in that school. The sample to be observed in this study were three classes derived from each grade respectively. The total students to be the sample consisted of 18 students from grade VII, 28 students from grade VIII and 17 students from grade IX.

Regarding the profile of the teacher to be the participant of this study, the researchers found that the teacher was the only English teacher in that school. The teacher was a graduate of English major with bachelor degree. Meanwhile, the school as the setting of this study was an Islamic School which owned Primary School preceeding the Secondary School. The Primary School was also an Islamic School.

As for the method of data collection, the study applied multiple instruments [11] [12]. The instruments applied in this study were non-participant classroom observations, document analysis, and interview. The classroom observation were conducted in a week. Subsequently, the interview toward the teacher was conducted the week after.

To analyze the data, the researchers analyzed the data inductively. The researchers also adopted the list of curriculum indicators in the research model [13] to assess the curriculum intent and implementation. The list of curriculum indicators is depicted in the following figure.

\begin{tabular}{cl} 
No. & Indicator \\
\hline $1 \mathrm{a}$ & There is a clear and coherent rationale for the curriculum design \\
\hline $\mathrm{b}$ & $\begin{array}{l}\text { Rationale and aims of the curriculum design were shared across the school and } \\
\text { appeared to be not fully understood by all }\end{array}$ \\
\hline $\mathrm{dd}$ & $\begin{array}{l}\text { Curiculum coverage allows all pupils to access the content and make progress through } \\
\text { the curriculum. }\end{array}$ \\
\hline $\mathrm{2b}$ & Curriculum principles include the requirements of centrally prescribed aims \\
\hline $\mathrm{c} \mathrm{c}$ & Reading is prioritized to allow pupils to access the full curriculum offer \\
\hline $3 \mathrm{a}$ & $\begin{array}{l}\text { Subject leaders at all levels have clear roles and responsibilities to carry out their role } \\
\text { in curriculum design and delivery }\end{array}$ \\
\hline $3 \mathrm{~b}$ & $\begin{array}{l}\text { Subject leaders have the knowledge, expertise and practical skill to design and } \\
\text { implement a curriculum }\end{array}$ \\
\hline $5 \mathrm{a}$ & $\begin{array}{l}\text { Curriculum resources selected, including textbooks, serve the school's curricular } \\
\text { intentions and the course of study and enable effective curriculum implementation }\end{array}$ \\
\hline
\end{tabular}




\begin{tabular}{ll}
\hline $5 \mathrm{~b}$ & The way the curriculum is planned meets pupil's learning needs \\
\hline $\mathrm{6a}$ & The curriculum has sufficient depth and coverage of knowledge in the subjects \\
\hline $7 \mathrm{a}$ & Assessment is designed truthfully to shape future learning. Assesment is not excessive \\
\hline $7 \mathrm{~b}$ & $\begin{array}{l}\text { Assessments are reliable. Teachers ensure systems to check reliability of assessments } \\
\text { in subjects are fully understood by staff. }\end{array}$ \\
\hline $7 \mathrm{c}$ & There is no mismatch between planned curriculum and delivered curriculum \\
\hline 8 & $\begin{array}{l}\text { The curriculum is successfully implemented to ensure pupils' progression in } \\
\text { knowledge successfully 'learn the curriculum' }\end{array}$ \\
\hline
\end{tabular}

Figure 1. List of Curriculum Indicators in the Research Model

Adopted from [13]

\section{Results and Discussion}

After conducting classroom observation, collecting data for document analysis and interview, this study revealed that there were two curriculum indicators not compatible with the list of curriculum indicators [13]. They are as follows:

1. Rationale and aims of the curriculum design were shared across the school and appeared to be not fully understood by all.

2. There is mismatch between planned curriculum and delivered curriculum.

The results of classroom observation and interview also revealed that the teachers did not implement student-centered learning as necessitated in both School-Based Curriculum and 2013 Curriculum. Then, materials taught solely depended on the textbook, not others. In addition, some approaches and methods as mentioned in the curriculum; Genre-Based Approach, ProjectBased Learning, Problem-Based Learning, were not employed in the classrooms. The further description of the classroom observation results is presented in the following table:

Table 1. The Results of Classroom Observation.

\begin{tabular}{lllll}
\hline & $\begin{array}{l}\text { Curriculum Used } \\
\text { as the Guideline. }\end{array}$ & $\begin{array}{c}\text { Curriculum } \\
\text { Implemented }\end{array}$ & $\begin{array}{c}\text { Teaching } \\
\text { Method/Approach }\end{array}$ & $\begin{array}{l}\text { Teaching } \\
\text { Materials }\end{array}$ \\
\hline Grade 1 & $\begin{array}{l}\text { Student-Centered } \\
\text { Curriculum (2013 } \\
\text { Curriculum) }\end{array}$ & $\begin{array}{l}\text { Teacher-Centered } \\
\text { Curriculum }\end{array}$ & GTM & $\begin{array}{l}\text { Descriptive, } \\
\text { Procedure } \\
\text { Text }\end{array}$ \\
\hline Grade 2 & Student-Based & Teacher-Centered & GTM & $\begin{array}{l}\text { Narrative, } \\
\text { Curriculum (SBC) } \\
\end{array}$ \\
& Curriculum & & $\begin{array}{l}\text { Recount } \\
\text { Text }\end{array}$ \\
\hline Grade 3 & Student-Based & Teacher-Centered & GTM & Narrative, \\
& Curriculum (SBC) & Curriculum & & Recount \\
& & & & Text \\
\hline
\end{tabular}




\section{Conclusions}

The conclusions to this study are represented in four inferences. First, discrepancy between curriculum design and it's implementation in the classrooms are tangibly seen. Second, teachers need to enlarge their knowledge and upgrade their skills in implementing curriculum in classroom setting. Third, in-house training and workshops are alternatives to undertake by teachers. Finally, schools need to control the relevance between curriculum goals and teaching practice.

\section{Implication}

The mismatch between the planned curriculum and the delivered curriculum conveys that the education bureaucracy requires to socialize more the 2013 curriculum to the teachers. The government also requires to regularly review and quality assure the subject to ensure that it is implemented sufficiently well. All in all, it is suggested that the government ensures that ongoing professional development/training is available for teachers to ensure that curriculum requirements can be met.

\section{References}

[1] Ministry of National Education and Culture.: Education Development in Indonesia 2014/2015. Jakarta: Center for Educational and Cultural Data and Statistics (2016)

[2] Lie, Anita.: Education Policy and EFL Curriculum in Indonesia: Between the Commitment to Competence and the Quest for High Test Scores. TEFLIN Journal. Vol.18, No.1, pp. 1-14 (2007)

[3] Hamied, F. A.: Curriculum Change: What does it mean to Indonesian TEFL?In Widodo, Handoyo Puji and Zakarias, Nugraheny, Recent Issues in English Language Education (pp. 13-38). Indonesia: UNS Press. (2014)

[4] Spolsky, B., \& Sung, K.: Secondary School English Education in Asia: From Policy to Practice. Routledge (2015)

[5] Chairani, N.: 2013 Curriculum Reflected in an International Oriented Senior High School, Yogyakarta. Sino-US English Teaching. Vol. 12, No. 8, pp. 568-574 (2015)

[6] Boston, C.: The Concept of Formative Assessment. ERIC Digest (2002)

[7] Taras, M.: Assessment-Summative and Formative-Some Theoretical Reflections. Brtish Journal of Educational Studies. Vol.53, No.4, pp. 466-478 (2005)

[8] Wininger, S.R.: Using Your Tests to Teach: Formative Summative Assessment. Teaching of Psychology. Vol.32, No.3, pp. 164-166 (2005)

[9] Rofik, Abdur.: School Readiness in Curriculum 2013 Implementation in English Lessons for State Junior High Schools in Wonosobo Regency. Post Graduate Thesis of Yogyakarta State University, Yogyakarta (2014)

[10] Sukirno.: The Implementation of Curriculum 2013 in English Language Teaching and Learning at SMP 1 Kajen Pekalongan. Post Graduate Thesis of Yogyakarta State University, Yogyakarta (2014)

[11] Cresswell, J. W.: Educational research. New Jersey: Prantice Hall (2010)

[12] Nunan, D.: Research methods in language learning. United States of America: Cambridge University Press (1992) 
[13] Ofsted.: An Investigation into How to Assess the Quality of Education through Curriculum Intent, Implementation and Impact. Phase 3 Findings of Curriculum Research, UK (2018) 